\title{
Achieving Global Food Security through Sustainable Development of Agriculture and Food Systems with Regard to Nutrients, Soil, Land, and Waste Management
}

\author{
Carlos G. H. Diaz-Ambrona • Emiliano Maletta
}

Published online: 4 April 2014

(C) Springer International Publishing AG 2014

\begin{abstract}
Ensuring that the food supply both keeps up with current population growth and changing food preferences are the main challenges of agriculture. Food security includes access to a sufficient amount of quality food products. Population growth, food preferences and economic wealth are variables that drive agricultural production, although agriculture does produce raw materials other than for food. The world population of 9 billion projected for 2050 will require food production to increase by $50 \%$ to $70 \%$, with raw materials and waste increasing by the same percentages. However, there will be no significant changes in the amount of arable land; the increase in production will come about through agricultural intensification, the disparity between real and potential yield being known as the yield gap. Innovation in management techniques will focus on optimizing water use, both for irrigated and rain-fed crops. In addition, nutrient management will have to be intensified to fill the production gap. Sustainable management focuses on improving nutrient efficiency, but also includes waste management. Sustainable agriculture must introduce a circular economy model and reverse logistics for waste management, and in particular to the nutrient cycle.
\end{abstract}

Keywords Crop $\cdot$ Environment $\cdot$ Farming $\cdot$ Natural resources $\cdot$ Water

C. G. H. Diaz-Ambrona $(\bowtie)$

Agricultural Systems Research Group, Department of Crop Production, Technical School of Agricultural Engineering, Innovation and Technology for Development Centre and CEIGRAM, Technical University of Madrid, Avda. Complutense, 28040 Madrid, Spain

e-mail: carlosgregorio.hernandez@upm.es

E. Maletta

International Consultant at Bioenergy Crops, Research Center for

Energy, Environment and Technology (CIEMAT), Avda.

Complutense 40, 28040 Madrid, Spain

e-mail: emiliano.maletta@ciemat.es

\section{Introduction}

Ensuring that the food supply keeps up with current population growth and improving the diet of a large part of the existing population are two of the biggest challenges facing modern agricultural engineering. It is projected that by 2050 , the world population will be more than 9 billion, and according to the Food and Agriculture Organization of the United Nations (FAO), food production will have to increase by between $50 \%$ and $70 \%$. At the end of the 21 st century, the global population will stabilize at around 10 billion, and a stable population can facilitate sustainable farming systems [1]. However, another more pessimistic projection is that the world's population will reach 25 billion if fertility rates remain the same [2]. There are important differences among nations. The populations of developed countries will remain the same or decline, whereas those of the developing countries will increase [3]. The global population growth rate is expected to decline to $0.35 \%$ by 2050 [3]. In addition, more of the population is concentrated in large cities, which need a continuous supply of food; people in cities demand more vegetables and food from animal products. In the more pessimistic situation, grain production would have to increase to 1 billion tons and meat production to 200 million tons. According to the World Food Summit of 1996 [4], food security is "when all people at all times have access to sufficient, safe, nutritious food to maintain a healthy and active life." Also, the United Nations estimates that the need for water will increase by $30 \%$ to cover food demand. According to Organization for Economic Co-operation and Development (OECD) environmental indicators for 2050 [5], there will have to be an increase in the water supply to avoid situations of food insecurity; however, the OECD projection estimates that $40 \%$ of the population will live in basins with a high level of water stress.

Future sustainable agriculture will have to meet the following challenges: 1) guarantee food security with regard to 
quantity, quality, price, and accessibility as products must be priced appropriately; high enough to ensure the standard of living of farmers, yet affordable to everyone, especially to people in urban areas; 2) maintain self-reliance of farmers in remote areas ( $50 \%$ of the world's poor are farmers), therefore necessary to improve the systems of production in those areas, improving traditional farming techniques while preserving local socially and culturally accepted varieties; marketable surpluses must be generated while increasing internal, i.e., local trade of products in the basic shopping basket; 3 ) reduce production variability by improving production techniques and increasing diversity of crops through investment in agricultural research; environmental risks (droughts, floods, freezing) must be prevented, and the effects of global environmental problems such as climate change in the medium and long term must be assessed; 4) preserve the environment by protecting the nutritional integrity of the soil, reducing runoff to adjacent water bodies, encourage biodiversity through diversification of crops, and reducing heavy chemicals use.

Agriculture provides the food necessary for life, through crops and animals. Furthermore agriculture provides up to $60 \%$ of the clothes we wear, the rest originating from petroleum or its derivatives. Moreover, plants provide more than $30 \%$ of the energy consumed by the world, primarily through the burning of biomass. Bioethanol and biodiesel are still innovative products that supply only $1 \%$ of the world's energy demands. Food consumption is directly proportional to the number of people, and the proportionality constant is on average $10.4 \mathrm{MJ} / \mathrm{d}$. The per capita energy consumption ranks from 0.4 to 8.5 tons of oil equivalent, and energy requirements depend on both the number of people and the level of development: the more development, the more energy is used. In any case, agriculture can never be a source of global energy; energy consumption rates in the world are higher than population growth (except in developing countries) and agricultural production growth [6]. Agriculture will however continue to provide an additional source of energy, limited mainly to rural and remote areas. Agricultural production for food or for energy requires different objectives: either the food itself; or for use as an energy source, and for biofuel the crops must be produced and managed energy-efficiently [7].

The cultivation of non-food alternatives has a high opportunity cost, as it uses resources that could otherwise be used to produce food crops. A non-food crop diverts the same resources required for production (soil, water, and nutrients), thereby competing with food. Therefore, there are fewer risks if all resources are dedicated to crops that can supply the food market, with any surpluses produced being used to obtain energy. Another alternative to avoid competition is to use abandoned or marginal land unsuitable for food production to obtain energy. Cultivating everything with food crops, regardless of the final destination, carries less risk of dividing the land between food and non-food crops.

\section{Population Growth}

In 1930, the total population of the planet was about 2 billion people. In 1975, that number had doubled, and at the end of the 20th century, it was 6.7 billion. Currently, the population is 7 billion. Never before has the human population grown so quickly. It has been able to do so because of the unprecedented success in modernizing agriculture and its effect on the growth of the food supply [8]. Feeding a growing population is the challenge. The population projection for 2050 is expected to be 9.2 billion, and food production must be increased by between $50 \%$ and $70 \%$. In the first case, the developed world will diminish its fat intake and reduce food waste; in the second case, if everything remains the same, better food will become available for the 0.8 billion people who are currently underfed $[9 \bullet \bullet]$.

World agricultural production annually has obtained an average $450 \mathrm{~kg}$ equivalent in cereal per capita, which would cover $90 \%$ of the "standard nutritional unit." The standard nutritional unit is enough to supply a person with all types of food for a balanced diet; losses include those that occur during storage and transportation and the seed necessary to plant the next crop. High-fat diets, which are associated with food high in animal fat and a sedentary lifestyle, require more than 800 equivalent kilograms of cereal per person per year, whereas a Mediterranean diet requires $620 \mathrm{~kg}$. Fresh plant products are more difficult to transport because of high water content, so in terms of price paid per unit of nutrient and energy, they are much more expensive. Overall, current agriculture feeds a larger population and does so with decreasing acreage. Given that a person eats approximately the same amount, this challenge has been met by an increase in productivity, hence by the intensification of agriculture.

There are three driving forces affecting the demand for products of agricultural origin: population growth; food preferences; and economic wealth. The pressure on farming systems to intensify production as a response to the increase in population is already the case in Asia, Central America, and South America, and to a lesser extent, in Africa. Europe and North America are not as pressured as China or South East Asian countries. However, Europe imports cereal (corn) and legumes (soybeans) from America, and palm oil from Indonesia and Malaysia to get cheaper prices on meat and milk, and to produce biofuels. This implies an importation of "virtual" land, water, and nutrients (nitrogen, phosphorus, potassium, and other micronutrients). If there are environmental impacts associated with production of the grain imported by the European Union (EU), then Europe generates those problems outside its borders. The EU effectively cultivates 35 million hectares outside its borders, whose production is earmarked for themselves [10]. This trend has increased with the policy of extensification (the term used by the EU Common Agrarian Policy to make farming less intensive and less 
productive per unit of land), sponsored by the Common Agricultural Policy, which creates tension in international markets (increased demand for rich countries), and causes shortages in markets of origin that cannot compete for prices and demand (i.e. Argentina).

Biomass harvested per capita and per year decreased slightly during the 20th century [11•]. The land-use efficiency decreased from 2.1 tons of total carbon produced annually by plant growth to 1.6 tons by 2005 (term used to describe human appropriation of net primary production, or HANPP). The replacement of forest or grassland with croplands reduces net primary production. However, it is possible to get more natural gain with adequate processes and management; net primary production is not the maximum potential, because there is a yield gap [12]. HANPP might grow to $29 \%$ by 2050 , or to $44 \%$ if providing large amounts of bioenergy [11•].

\section{Global Food Demand}

There are two ways to increase global food production: 1) expand the agricultural area and;2) increase yields per unit of area and per year; however, both are related to a given production [7]. Intensification due to increasing the harvest frequency of croplands might increase crop production [13•]. Ray and Foley [13•], using data from the FAO, showed that in the past 50 years, cropland area increased from 1.37 billion hectares to 1.55 billion hectares, and annual harvest land increased from 1.06 billion hectares to 1.38 billion hectares. On average, $89 \%$ of croplands were harvested as a consequence of reduced fallowing or increased annual crop sequences. These data show agricultural intensification. However, Africa has the greatest potential to increase harvest frequency; the authors found no relationship between the number of harvests per year and an increase in crop production [13•]. They mistake the relationship between the concept of crop development and crop growth; development is the anatomical and physiological changes of plants during their life cycle; and growth is the increase in weight or volume of the plant. Harvest is therefore a consequence of development, and production is a consequence of growth. Increasing the number of stages of development, in particular the number of harvests per year, is no guarantee that growth is greater when compared to a smaller number of harvests; although a lower ratio of harvests may indicate either fallowing or crop cycles exceeding a year. There is only a small area of land able to support crops continuously; extreme temperatures or dry periods limit the crop season during the year. There is also a difference between harvesting perennial and annual crops. The number of harvests might increase the annual yield of perennial crops, if cutting maintains part of the leaf. In the case of annual crops, it is better to grow a long-season variety than a short-season variety. During the crop establishment phase, leaf area grows slowly; it takes many days to reach the optimum leaf index to achieve the maximum grow rate. Crop transplanting is a technique used to reduce the duration of this phase.

\section{Sustainable Development of Agriculture and Food Systems}

Sustainability is a complex term used to characterize agriculture according to the degree of fulfillment of certain goals. These goals are related to agro-ecologic, environmental, and socio-economic dimensions. Sustainability is the dynamic and temporal character of a system. In absolute terms, there is no ending value because the objective changes as its dimensions change through time. Some authors have used "sustainable" as a synonym for organic farming or lowinput farming; however, that is not precise, because all agricultural systems must be analyzed through the perspective of sustainability.

Organic agriculture cannot feed the world, the limiting factor being the nutrient supply. Organic nutrients come from plant biomass or are transformed to compost or animal manure. The only source of nitrogen is biologic $\mathrm{N}$-fixation by legumes, which must be included in crop rotations, using extra land, labor, water, and other nutrients. High-input organic farmers are limited by the extra land needed to obtain organic manure; there are no possibilities to increase the actual numbers $[14 \bullet]$.

The international agricultural market covers around $10 \%$ of total agricultural production. That means there is a global market for nutrients, water, and land. A report by the Observatory for Productivity and Efficient Use of Resources in Agriculture (OPERA) shows that the EU uses 50 million hectares of cropland overseas, mainly in South America (Brazil and Argentina), North America (USA and Canada), South East Asia, and Australia [10]. Nutrients must be returned to those lands. Today, in the developing countries and remote areas there are many small farmers using non-certified organic systems with no other options. Famine and poverty are common among those farmers; according to the FAO $75 \%$ of poverty is in rural areas, and it is driven by lack of resources, low output, and unsustainable practices, rather than the adoption of the principles of organic agriculture [15].

\section{Land}

During the past century, expansion of the croplands helped to increase the food supply. Intensification of agriculture in the developed countries has reduced cropland usage. The best soils of the Earth are already under cultivation, occupying nearly 1.5 billion hectares (10\% of the Earth's surface). An 
extension of acreage would result in more easily eroded or nutrient-poor soils for cultivation. For example, grasslands represent a total of approximately 3.5 billion hectares. Other lands prevent release or are protected territory for natural ecosystems. The issue is not trivial. We must choose between more intensive agriculture and more natural spaces; or more extensive agriculture and fewer natural spaces. The question is: How much surface do we want to maintain as natural ecosystems? Urbanization, the expansion of artificial surfaces, is a major cause of agricultural land loss on our planet. Urban agriculture reduces this impact more in developing countries than in developed countries [16, 17]. Urban agriculture is the production of food in, or around, the urban areas to minimize the energy required in transportation of fresh and residual produce; in 2050, around $75 \%$ of world population will live in cities. In Africa urban agriculture provides a significant share of income for the urban poor; there is also fairly consistent evidence of a positive statistical improvement in the dietary adequacy indicators [18].

Since 1992, the EU Common Agricultural Policy reform (MacSharry reforms) has set aside 40 million hectares of cropland out of production [5]. The abandonment of cropland is a global phenomenon. For example, China has established a "red line" to prevent a reduction in 120 million hectares of cropland, after the abandonment of the fields in only a few years resulted in a decrease from 130 million hectares to 122 million hectares in 2008, approaching the minimum. The policy allows farmers to maintain production of 550 million tons of cereal grain. Production is complemented with imports and produced on land purchased or leased from other countries, especially in Africa and the Americas.

According to Cai et al. [19], there are 320 million to 702 million hectares available for biofuel production in Africa, China, Europe, India, South America, and the continental USA. The authors consider this land "marginal agricultural land," defining marginal land as "abandoned and degraded cropland and mixed crop and vegetation land, usually of low quality." However, marginal land also has marginal yield [6], and the potential biofuel production is overestimated for those lands [19]. Because energy salvaging is possible only with long harvest cycles, associated mainly with perennial plants accumulating biomass during several years, it is a lowintensity harvest. Land available for bioenergy production is estimated from 56 million to 103.5 billion hectares, depending on the scenario and the rule set used from high-resolution satellite imagery, although these estimates are uncertain [20•]. For the USA, marginal lands have a significant potential for renewable energy. Energy is obtained in different ways: photovoltaic; concentrating solar power; wind; hydrothermal-geothermal; mini-hydro systems; biomass power; and landfill gas to energy. Overall the solar technologies present the greatest opportunity, followed by wind and biomass power. Biomass power potential is concentrated in the eastern USA [21].
There is evidence that biofuel expansion cannot be linked to the net harvested area dedicated to food production [22••]. Both biofuel crop areas and croplands harvested for food, feed, and fiber markets increased in most countries, including the USA and Brazil. The relevance of this study reflects the fact that most alarmist claims and criticism, against biofuel expansion because of land competition, might be mistakenly evaluated. The multi-cropping systems that biofuel production may allow possibly overlook several synergies, such as those of co-products, double-cropping systems, and fallow reduction. From 2000 to 2010, more than 34 major biofuelproducing nations had an increase of 14 million hectares of cropland; at the same time, increased cropping intensity created more than 42 million hectares of extra cropland [22••]. Biofuel crop areas and net harvested crop area increased in most countries, including the USA and Brazil, from 2000 to 2010. The conclusion therefore is that biofuel expansion is not associated with a decline in the area available for food crop production.

\section{Water}

Water is one of the most prized land elements. Life arises from and moves around water. Plants depend on its availability while acting as very efficient conductors of the flow of water that penetrates from the soil through roots and stems, then through leaves, and then out into the atmosphere. Crops need large amounts of water. Only $6.1 \%$ of the renewable fresh water supply is the human appropriation of accessible runoff [23]. Most water is found in the oceans $(97.4 \%)$ with the rest in ice, polar lands, and glaciers (2\%). Freshwater distribution is irregular; some areas, such as the Amazon basin, have large quantities of water with minimal human usage, whereas others, such as Saharan Africa, have very little availability.

Agricultural water requirements are calculated by estimating crop evapotranspiration needs, assuming current levels of water depending on crop productivity and management [24]. Transpiration water is linearly correlated with crop biomass. For example, the amount of water needed to produce a kilogram of grain under appropriate conditions varies from $1000 \mathrm{~L}$ for rice to $500 \mathrm{~L}$ for maize. Regulated waters are focused as a service for irrigating land; for this reason, irrigation uses $70 \%$ of regulated waters globally. Transpired water always returns to the atmosphere. For every $2 \mathrm{~L}$ of water a person needs to drink per day, $2000 \mathrm{~L}$ are used for the primary production of that person's balanced diet. Improvements in yields of both rain-fed and irrigated crops have increased water usage. According to Brauman et al. [25•], irrigated cropland and the demand for water will increase significantly by 2050 ; they disagree with the projection made by the OECD [5] showing a decline in the demand for water for irrigation. 
The FAO [26] estimates that the limit of poverty related to water is a minimum of $700 \mathrm{~m}^{3}$ of available water per person per year. The water used to produce food for the diet of an average person is 10 times greater than the amount necessary for other uses. Taking into account the nutritional standard unit of $500 \mathrm{~kg}$ of cereal per person, the amount of water needed to produce rice and maize is $500 \mathrm{~m}^{3}$ and $250 \mathrm{~m}^{3}$ per person per year, respectively. For example, in Egypt, a country based on irrigation, the forecast is that by 2025 the quantity of available water per capita will decrease to $500 \mathrm{~m}^{3}$ per year [27]. It is well-documented that irrigation contributes to the alleviation of hunger and poverty in Asia and Africa, although success is not reached in all cases [28, 29]. These values alone show that agriculture is the activity for which most water is needed. Water is the main renewable resource required for cultivation. Moreover, not only is a certain amount of water required, but that water should be available in the quantity needed throughout the production cycle. Managing the availability of both rain and irrigated water is critical for successful agriculture.

Efficiency in the use of water (or its inverse, the virtual water of crop) depends on physiologic factors of the crop species, the environment, and crop management. Thus, for example, efficiency is greater in plants that have a photosynthetic mechanism called $\mathrm{C} 4$, including crops such as maize, sorghum, and sugar cane, which are adapted to tropical and subtropical climates and, therefore, do not grow in environments with average temperatures below $10{ }^{\circ} \mathrm{C}$, as compared with $\mathrm{C} 3$ species such as wheat and barley. Meanwhile, intensive growing in greenhouses allows control of meteorological variables that affect crop performance, raising the efficiency of water use to the maximum. For example, in the case of tomatoes and beans, water use efficiency is almost 3.5 times greater in greenhouse than outdoor cultivation.

To better understand the importance of water in agricultural production, we show two examples (Fig. 1). The first is the evolution of wheat yields under rain-fed conditions on a chronologic scale from 1922 to 2010 for two areas of Spain: one in Albacete province, representative of a semi-arid Mediterranean area in the southeast; and the other in Lugo province, representative of a temperate wetland in the northwest. The yield trend for wheat in the initial years of the 20th century was decreasing until 1950 (Fig. 1). This downward trend does not occur linearly; rather, there are years in which performance falls miserably (variations between $400 \mathrm{~kg} / \mathrm{ha}$ and $1200 \mathrm{~kg} / \mathrm{ha}$ ) because of the recurrence of rainy and dry cycles. From 1950, and coinciding with the start of the socalled green revolution, there is a change in the trend. Two phenomena are observed from 1950: one is marked by a line showing maximum yields, which rises at a rate of $40 \mathrm{~kg} / \mathrm{ha}$ per year as wheat yields begin to increase; the other encompasses minimum yields, and variations can be seen in the performance against this trend that usually coincide with years of poor rain or other weather factors despite improvements in cultivation, seeds, fertilizers, and machinery. Lack of rain is decisive, for these technologic improvements remain without effect. In Lugo, where the production level initially is greater but the behavior is similar, there is an initial downward trend in the yield of wheat until 1967. This downward trend, as in Albacete, was not linear, but there are years in which performance falls and others in which it even increases (19471961). From 1967, there is a change in the trend; wheat yields start to rise, although some years show slight decreases in performance that often coincide with years of poor rain; however, unlike Albacete, there is a ground line.

The second example is the evolution of maize yields under irrigation in a Mediterranean region of Albacete in southeast Spain (Fig. 1). Initially, a constant trend may be observed; then, between 1922 and 1954 there is a decrease. This year, there is a change in the trend, which happens to be growing at a rate of $243 \mathrm{~kg} / \mathrm{ha}$ per year. No doubt, improvements in irrigation techniques coupled with the application of the green revolution (fertilizers, selected seeds, improvement in machinery) have made this possible. In addition, in this case, irrigation allows higher productivity and decreases variability, or the risk of having years with famine or lack of a food supply.

Irrigation has contributed to yield stabilization and an increase in productivity. Water resources must be managed properly. In some regions of Asia and the Middle East, the ground water table is falling quickly because of a lack of regulated water and high demographic pressure [31]. The key factors causing water/food-induced conflicts [31] are water scarcity and population growth; mismanagement of water; problems in trans-boundary river basin management; limited information on water resource availability; water policy overlaps; water quality degradation and pollution; structural imbalance; problems with management authorities; limited awareness of water issues; a slow transfer of technology; a shortage of capacity building and institutional development; inadequate stakeholder participation; a shortage of available funds; and poor public awareness programs.

The growing meat demand is related to an increase in grain production; it is estimated that 1 billion tonnes of grain is dedicated to feed animals annually, but crop and livestock are complementary, as half of world's food comes from mixed farming [32•]. Ruminants eat high fiber plants that are unsuitable for human. Pasture management and improvement can help to sustain livestock [32•].

\section{Soil and Nutrients}

According to Jones et al. [33••], agricultural sustainability can be fulfilled only by using a whole-systems approach that considers nutrient stocks, removal, export, and recycling. They stated that the current rates of soil nutrient deliveries 

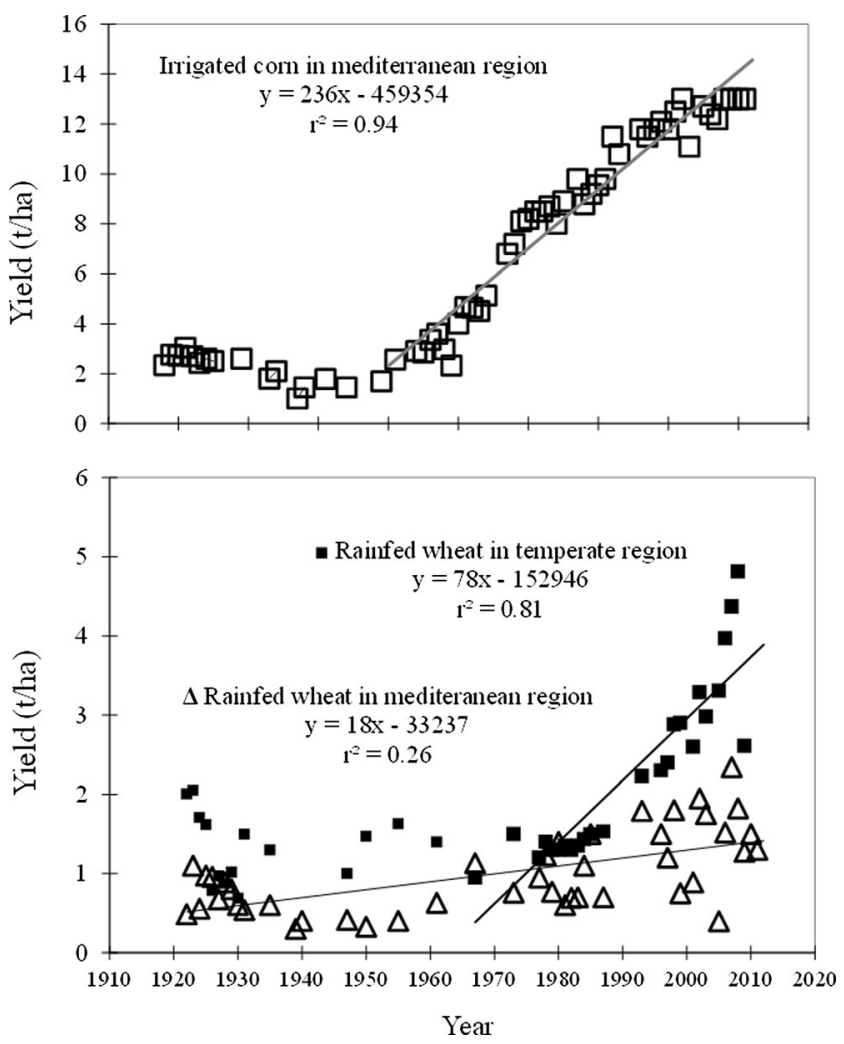

Fig. 1 Evolution of yield from irrigated corn and rain-fed wheat in the Mediterranean region of Albacete (southeast Spain) and rain-fed wheat in the temperate region of Lugo (northwest Spain). (Data from MAGRAMA [30])

must be reduced and the use of synthetic fertilizers made more efficient. Taking into account that more food needs leads to more nutrient reduction, nutrient use must become more efficient. Nowadays, fertilizers incorporate complete doses of macronutrients and micronutrients for any crop, but fertilizers must be used properly to avoid or minimize leaching, volatilization and other losses [34•]. Nutrient deficiencies are rare in developed countries but micronutrient deficiencies are common in the less-developed countries [33••]. Integrated soil fertility management is a new approach to raising productivity levels while maintaining natural resources [35]. Integrated soil fertility management focuses on restoring soil nutrient pools, reducing nutrient losses, and improving efficiency. The cycle of sustainability must facilitate the return of all farm resources back to the field. The pathways of the elements are different (Fig. 2). Water, carbon, and nitrogen are transferred through the atmosphere, whereas phosphorus, potassium, and micronutrients flow through organic matter or in water solution. The closeness or remoteness of each level contributes to the achievement of sustainability.

Nitrogen $(\mathrm{N})$ inputs to croplands have been, and will continue to be, an important contributor to obtaining more food; however, a proportion of the $\mathrm{N}$ input is not taken up by crops and leaves the field, contributing to air or water pollution. Conant et al. [36•] constructed a nitrogen input database from

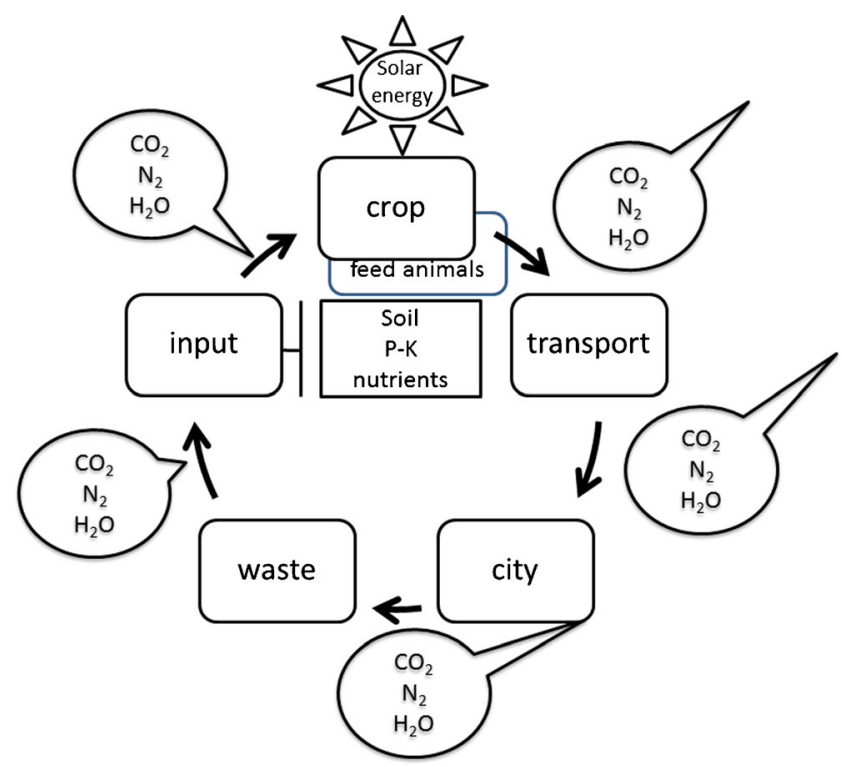

Fig. 2 Theoretical simplified flow diagram for agricultural sustainability. Carbon, water, and nitrogen cycles comprise the atmosphere nutrients from soil that are transported through the food chain; the pumped energy is provided by the sun

the 1960s through to 2007. These data show a positive correlation between yields and increased $\mathrm{N}$ fertilization. Also, they show that aggregate yields in OECD countries are $70 \%$ greater than in non-OECD countries, with the $\mathrm{N}$ input rates at just $54 \%$ greater, suggesting that nitrogen management by OECD countries is better than that of non-OECD countries [37]. This suggests that there is a gap in improvements through enhanced $\mathrm{N}$ delivery and uptake in the world's lowyielding crop areas which will increase efficiency of $\mathrm{N}$ use; it is an important factor to meet food demand in the future.

Today, nitrogen loads might be an important source of $\mathrm{N}$ in low-input systems, such as in organic agriculture; as well as in the USA [38] and China [39], which are countries with high industrial activity and fuel consumption. Long-term unfertilized croplands increase crops' $\mathrm{N}$ uptake [39].

Phosphorus $(\mathrm{P})$ will be the limiting macronutrient in croplands; it is an essential plant nutrient and a nonrenewable resource, and is being consumed at a rate of $23.5 \mathrm{Tg} /$ year [40]. The global demand for $\mathrm{P}$ is estimated to increase $1.5 \%$ annually, and at that rate, supplies would be exhausted in 100 to 250 years [41]. Phosphorus deficit in the agricultural system is estimated to occur in almost $30 \%$ of global croplands [42]. Therefore, the rational use of $\mathrm{P}$ reserves is essential to sustainable agriculture [43]. This use involves efficient management of soil, fertilizer and recycling, and water quality.

Sustainable management of fertilizers also focuses on other nutrients. Complex fertilizers that incorporate more than the three macronutrients perform better. For example, wheat yields were higher when the crops were fertilized with organic manure plus NPK (K=potassium), than with only NPK applying the same quantity of nitrogen [44]. This study showed that long- 
term application of organic manure with inorganic fertilizers improved the synchrony between nitrogen supply and wheat demand and increased nitrogen use efficiency and grain yield.

\section{Waste Management}

Agricultural waste refers to many goods used in the production process (from the farm to fork), which the farmer or costumer discards, intends to discard or is required to discard [45]. Waste can be classified into natural or non-natural; and by type of substance, liquid, solid, or gaseous. Natural wastes are crop waste, food waste, livestock waste, dust and gases, and other natural products. Non-natural wastes are packaging; plastics (silage films, greenhouse films, horticultural films, bale twine and net-wrap, cores, tree guards and other plastics); cardboard cores; agrochemicals; animal health waste (sheep dip, unused medicines, syringes and needles, dressings and swabs, aerosols); machinery waste (oil, batteries, tires and other machinery/equipment); and building waste (concrete, metal and others). For a farming system approach, waste management is an important issue to be included. In all cases, wastes are a proportion of the original material.

Non-natural waste must be managed properly to prevent contamination and toxic damage to the environment or to humans. Natural wastes have three main applications: compost; animal feed; and energy production (biomass and methane). In the cycle of nature and agricultural systems, the key is to return nutrients and materials to the field. If agriculture extends from field to folks, we need to close the cycle from folks back to the field. This simple principle is regulated by thermodynamic rules and entropy. Waste management of natural products in agriculture must be considered along the trophic chains. In farming systems, animals appear to use plant materials unsuited for human consumption.

Crop and animal waste contains organic matter and nutrients that must be returned to the fields that generated them. With regard to nutrient cycling, losses occur during all phases. For example, nutrients transferred from a pig farm to the compost pile contain $29 \%$ of total nitrogen, $87 \%$ of phosphorus, $34 \%$ of potassium, and $75 \%$ of magnesium [46]. Municipal sewage applications can be a source of nutrients, but the particulatesludge from municipal sewage might result in soil contamination, accumulation of trace elements, and phytotoxicity depending on the urban and industrial activities. Residue retention is an innovative management solution for high-yield crops for biomass crop waste. High-yield rice varieties produce high residues. In one study, total system productivity increased by $11 \%$ to $16 \%$ through management with residue retention in permanent wide-bed planting and zero tillage [47].

According to the (FAO), uneaten food is estimated to account for $30 \%$. This percentage is divided into food loss and food waste [48]. Food loss is the produce lost during the post-harvest, processing, packaging and delivery processes, and includes biomass originally meant for human consumption but eventually used for other purposes. Food waste is food loss occurring during the retail and final consumption stages, due to the behavior of retailers and consumers. Kusch and Evoh [49॰] suggested that food waste might be a source for bioenergy. They considered that better management of the food chain and food wastage might contribute to food security and recover energy and other resources; a third of all food is lost across the food supply chain [50]. In the sugar beet manufacturing industry, sugar factory lime is used to produce a fertilizer as a calcium source; this byproduct is calcium carbonate containing up to $50 \% \mathrm{CaO}$ and other nutrients.

The circular economy model and reverse logistics in agriculture are applied to material management [51]. Reverse logistics covers all the operations related to the re-use of products and materials. We must consider crop and food nutrients in the circular economy model. Although there are some estimates of food waste, how much is actually wasted is not well-known, as the estimates focus mainly on fresh produce [52]. Forty-two percent of food waste occurs in households, $39 \%$ in the food manufacturing industry, $14 \%$ in catering and restaurants, and $5 \%$ in the distribution chain, and waste is projected to rise to about $126 \mathrm{Mt}$ by 2020 [52].

\section{Conclusions and Final Remarks}

The future of agriculture is uncertain. In the context of climate change, there will be losers and winners [53, 54]; however, this is not new in the history of agriculture. Parts of Africa, southern Europe, and southern and eastern Asia have been projected to be particularly negatively affected, whereas northeastern Europe and northern America might experience more favorable conditions for agriculture. Achieving global food security will depend on the relationship between the farmer and the rest of the population, who mainly have an urban and sedentary lifestyle [55]. The sustainable development of agriculture is a complex issue. Meeting food demand is and will be the main feature of agriculture, and sustainable food systems will become even more critical. Re-engineering of agricultural practices for the optimum management of land, water, soil, nutrients, and waste management from a systemic point of view will be the key.

Acknowledgments The authors thank the Regional Government of Madrid (Spain) for supporting the research project AGRISOST Sustainable Agronomic Systems: Biomass Production and Management of C, N, and Water, and the Spanish Ministry of Economy and Competitiveness and the European Regional Development Fund for supporting the Project On-Cultivos: Development, Demonstration and Evaluation of the Viability of the Commercial Production of Energy from Dedicated Crops in Spain. Also we thank Professor David Connor and María Ines Mínguez for their helpful comments on this manuscript. 


\section{References}

Papers of particular interest, published recently, have been highlighted as:

- Of importance

- Of major importance

1. DeLong JP, Burger O, Hamilton MJ. The UN medium population projection is an unstable equilibrium. Front Ecol Environ. 2013;11: 65-6.

2. Cleland J. World population growth; past, present and future. Environ Res Econ. 2013;55:543-54.

3. Behrman J, Kohler HP. Population quantity, quality, and mobility. Working Paper 2. Geneva: Global Citizen Foundation; 2013.

4. World Health Organization. Food Security. Geneva: World Health Organization; 2014. Available at http://www.who.int. Accessed 2 Jan 2014.

5. Organization for Economic Co-operation and Development. OECD Environmental outlook to 2050: the consequences of inaction. Paris: OECD Publishing; 2012.

6. Connor DJ, Hernandez CG. Crops for biofuel: current status, prospects and limitations for future. In: Howarth RW, Bringezu S, editors. Biofuels: Environmental Consequences and Interactions with Changing Land Use. Proceedings of the Scientific Committee on Problems of the Environment (SCOPE) International Biofuels Project Rapid Assessment 2009; Gummersbach, Germany. Ithaca: Cornell University; 2009. p. 65-80.

7. Connor DJ, Loomis RS, Cassman KG. Crop ecology. Production and management of agricultural systems. Cambridge: Cambridge University Press; 2011.

8. Evans LT. Feeding ten billion: plants and population growth. Cambridge: Cambridge University Press; 1998.

9.• Connor DJ, Mínguez MI. Evolution not revolution of farming systems will best feed and green the world. Glob Food Secur. 2012;1:106-13. This article provides a detailed comparison between organic and modern agricultural systems.

10. Von Witzke H, Noleppa S. EU Agricultural Production and Trade: Can more efficiency prevent increasing 'land-grabbing'outside of Europe? OPERA. Berlin: Humboldt University; 2010.

11. Krausmann F, Erb KH, Gingrich S, Haberl H, Bondeau A, Gaube V, et al. Global human appropriation of net primary production doubled in the 20th century. Proc Natl Acad Sci U S A. 2013;70(25): 10324-9. This paper shown efficiency gains of human appropriation of net primary during the last century, these trends will continue, they suggest refocusing the energy economy on bioenergy.

12. Smith D. Natural gain: in the grazing lands of southern Australia. Melbourne: NewSouth Publishing; 2000.

13. Ray DK, Foley JA. Increasing global crop harvest frequency: recent trends and future directions. Environ Res Lett. 2013;8:044041. This is a good study analyzing harvest and land use by crop.

14. Connor DJ. Organically grown crops do not a cropping system make and nor can organic agriculture nearly feed the world. Field Crops Res. 2013;144:145-7. This article presents further discussion about systems analysis in crop studies.

15. Parrot N, Olensen JE, Høgh-Jensen H. Certified and non-certified organic farming in the developing world. In: Halberg N, Alrøe HF, Knudsen MT, Kristensen ES, editors. Global development of organic agriculture: challenges and prospects. Oxfordshire: CABI Publishing; 2006. p. 153-80.

16. Bersaglio B, Kepe T. Farmers at the edge: property formalization and urban agriculture in Dar es Salaam, Tanzania. Urban Forum. 2013; doi:10.1007/s12132-013-9214-0.
17. Wortman SE, Lovell ST. Environmental challenges threatening the growth of urban agriculture in the United States. J Environ Qual. 2013;42(5):1283-94.

18. Zezza A, Tasciotti L. Urban agriculture, poverty, and food security: empirical evidence from a sample of developing countries. Food Policy. 2010;35(4):265-73.

19. Cai X, Zhang X, Wang D. Land availability for biofuel production. Environ Sci Technol. 2010;45(1):334-9.

20. Fritz S, See L, van der Velde M, Nalepa RA, Perger C, Schill C, et al. Downgrading recent estimates of land available for biofuel production. Environ Sci Technol. 2013;47(3):1688-94. The authors estimated roughly world land availability for bioenergy production from 56 to 1035 million hectares depending upon the climate change scenario.

21. Milbrandt AR, Heimiller DM, Perry AD, Field CB. Renewable energy potential on marginal lands in the United States. Renew Sust Energy Rev. 2014;29:473-81.

22.• Langeveld JWA, Dixon J, van Keulen H, Quist-Wessel PMF. Analyzing the effect of biofuel expansion on land use in major producing countries: evidence of increased multiple cropping. Biofuels Bioprod Bioref. 2014;8(1):49-58. This article provides detailed information about land uses for crop diversity.

23. Postel SL, Daily GC, Ehrlich PR. Human appropriation of renewable fresh water. Science. 1996;271(5250):785-8.

24. Vaux H. Water for agriculture and the environment: the ultimate trade-off. Water Policy. 2012;14:136-46.

25. Brauman KA, Siebert S, Foley JA. Improvements in crop water productivity increase water sustainability and food security-a global analysis. Environ Res Lett. 2013;8(2):024030. This is a good commentary on water use by crops and sustainability.

26. Food and Agriculture Organization of the United Nations. Irrigation management transfer: worldwide efforts and results. FAO Water Report \#32. International Water Management Institute, Sri Lanka and Food and Agricultural Organization, Rome; 2007.

27. NWRP. Water for the future. National Water Resources Plan. Ministry of Water Resources and Irrigation, Egypt; 2005. Available at http://ocid.nacse.org/. Accessed 2 Jan 2014.

28. García-Bolaños M, Borgia C, Poblador N, Dia M, Seyid OMV, Mateos L. Performance assessment of small irrigation schemes along the Mauritanian banks of the Senegal River. Agric Water Manag. 2011;98(7):1141-52.

29. Borgia C, García-Bolaños M, Li T, Gómez-Macpherson H, Comas $\mathrm{J}$, Connor D, et al. Benchmarking for performance assessment of small and large irrigation schemes along the Senegal Valley in Mauritania. Agric Water Manag. 2013;121:19-26.

30. MAGRAMA. Anuarios de Estadística Agraria. Madrid: Secretaría General Técnica. Ministerio de Agricultura, Alimentación y Medio Ambiente; 2013. Available at http://www.magrama.gob.es. Accessed 2 Jan 2014

31. Hefny MA. Changing behaviour as a policy tool for enhancing food security. Water Policy. 2012;14:106-20.

32. Eisler MC, Lee MRF, Tarlton JF, Martin GB, Beddington J, Dungait JAJ, et al. Agriculture: steps to sustainable livestock. Nature. 2014;507(7490):32-4. The authors discuss about the steps to sustainable livestock management focuses on ruminants.

33.• Jones DL, Cross P, Withers PJ, DeLuca TH, Robinson DA, Quilliam RS, et al. Nutrient stripping: the global disparity between food security and soil nutrient stocks. J Appl Ecol. 2013;50(4):85162. This article provides detailed analyses for understanding the relationship between soil nutrients and food security.

34. Cameron KC, Di HJ, Moir JL. Nitrogen losses from the soil/plant system: a review. Ann Appl Biol. 2013;162(2):145-73. This paper shows the best management practices of temperate soil and plant systems that can improve the sustainability of agriculture and reduce its impact on the environment. 
35. Maqsood MA, Hussain S, Aziz T, Ashraf M. Sustainable agriculture through integrated soil fertility management on degraded lands. In: Shahid SA, Abdelfattah MA, Taha FK, editors. Developments in Soil Salinity Assessment and Reclamation: Innovative Thinking and Use of Marginal Soil and Water Resources in Irrigated Agriculture. Amsterdam: Springer Netherlands; 2013. p. 759-768.

36. Conant RT, Berdanier AB, Grace PR. Patterns and trends in nitrogen use and nitrogen recovery efficiency in world agriculture. Global Biogeochem Cycles. 2013;27(2):558-66. This article provides detailed pathways for nitrogen use in agriculture.

37. OECD. Environmental performance of agriculture in OECD countries since 1990. Paris: Organization for Economic Co-operation and Development; 2008. Available at http://www.oecd.org/. Accessed 2 Jan 2014.

38. Sobota DJ, Compton JE, Harrison JA. Reactive nitrogen inputs to US lands and waterways: how certain are we about sources and fluxes? Front Ecol Environ. 2013;11(2):82-90.

39. Zhang F, Chen X, Vitousek P. Chinese agriculture: an experiment for the world. Nature. 2013;497(7447):33-5.

40. Carpenter SR, Bennett EM. Reconsideration of the planetary boundary for phosphorus. Environ Res Lett. 2011;6:014009.

41. Cordell D, Drangert JO, White S. The story of phosphorus: global food security and food for thought. Global Environ Chang. 2009; 19:292-305.

42. MacDonald GK, Bennett EM, Potter PA, Ramankutty N. Agronomic phosphorus imbalances across the world's croplands. Proc Natl Acad Sci U S A. 2011;108:3086-91.

43. Haygarth PM, Delgado A, Chardon WJ, Litaor MI, Gil-Sotres F, Torrent J. Phosphorus in soils and its transfer to water: from finescale soil processes to models and solutions in landscapes and catchments. Soil Use Manag. 2013;29(s1):1-5.

44. Liang B, Yang X, Murphy DV, He X, Zhou J. Fate of 15N-labeled fertilizer in soils under dryland agriculture after 19 years of different fertilizations. Biol Fertil Soils. 2013;49:977-86.
45. Loehr R. Agricultural Waste Management: problems, processes, and approaches. New York: Academic Press; 1974.

46. Luo Y, Stichnothe H, Schuchardt F, Li G, Huaitalla RM, Xu W. Life cycle assessment of manure management and nutrient recycling from a Chinese pig farm. Waste Manag Res. 2014;32(1):4-12.

47. Naresh RK. Rice residues: from waste to wealth through environment friendly and innovative management solutions, its effects on soil properties and crop productivity. Int J Life Sci Biotech Pharm Res. 2013;2(1):133-41.

48. Pitesky M, Gunasekara A, Cook C, Mitloehner F. Adaptation of agricultural and food systems to a changing climate and increasing urbanization. Curr Sustain Renew Energy Rep J. 2014;40518.

49. Kusch S, Evoh CJ. Meeting the growing demand for food and bioenergy in the 21st century: synergies through efficient waste management. Biofuels. 2013;4(5):479-83. This article analyzes uses of waste as a source of energy and recovery of nutrients for crop production.

50. Parfitt J, Barthel M, Macnaughton S. Food waste within food supply chains: quantification and potential for change to 2050 . Philos Trans R Soc B London Biol. 2010;365:3065-81.

51. Nakhata C, Stock JR, Texiera TB. Doctoral dissertations in logistics and supply chain-related areas: 2005-2009. Logist Res. 2013;6(4): 119-31.

52. Mirabella N, Castellani V, Sala S. Current options for the valorization of food manufacturing waste: a review. J Clean Prod. 2014;65: 28-41.

53. Beck J. Predicting climate change effects on agriculture from ecological niche modeling: who profits, who loses? Clim Chang. 2013;116(2):177-89.

54. Lal R. Climate strategic agriculture and the water soil waste nexus. J Plant Nutr Soil Sci. 2013;176(4):479-93.

55. Briz J, Köhler M, Felipe I. Green Cities in the World: progression, innovation, organization. Madrid: Editorial Agricola Española; 2014. 